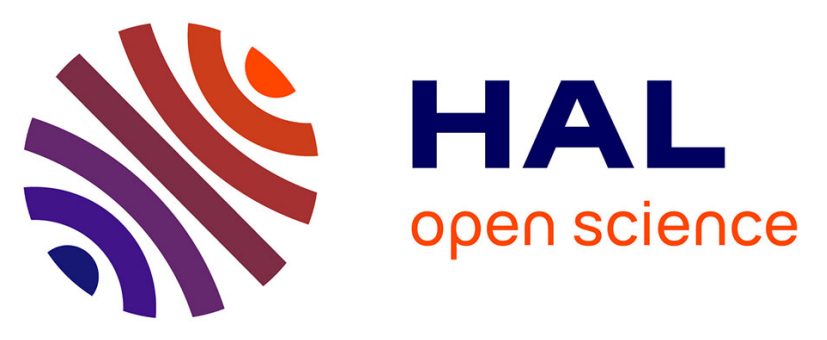

\title{
Small-Pore Gallates MOFs for Environmental Applications: Sorption Behaviors and Structural Elucidation of Their High Affinity for CO 2
}

Nicolas Heymans, Sandrine Bourrelly, Périne Normand, Emily Bloch, Hassan

Mkhadder, Lucy Cooper, Martin Gorman, Intissar Bouzidi, Nathalie Guillou, Guy de Weireld, et al.

\section{To cite this version:}

Nicolas Heymans, Sandrine Bourrelly, Périne Normand, Emily Bloch, Hassan Mkhadder, et al.. SmallPore Gallates MOFs for Environmental Applications: Sorption Behaviors and Structural Elucidation of Their High Affinity for CO 2. Journal of Physical Chemistry C, 2020, 124 (5), pp.3188-3195. 10.1021/acs.jpcc.9b11535 . hal-02493857

\section{HAL Id: hal-02493857 https://hal.science/hal-02493857}

Submitted on 2 Dec 2020

HAL is a multi-disciplinary open access archive for the deposit and dissemination of scientific research documents, whether they are published or not. The documents may come from teaching and research institutions in France or abroad, or from public or private research centers.
L'archive ouverte pluridisciplinaire HAL, est destinée au dépôt et à la diffusion de documents scientifiques de niveau recherche, publiés ou non, émanant des établissements d'enseignement et de recherche français ou étrangers, des laboratoires publics ou privés. 


\section{Small Pore Gallates MOFs for Environmental}

\section{Applications: Sorption Behaviors and Structural Elucidation of their High Affinity for $\mathrm{CO}_{2}$}

Nicolas Heymans, ${ }^{a}$ Sandrine Bourrelly, ${ }^{b}$ Perine Normand, ${ }^{a}$ Emily Bloch,${ }^{b}$ Hassan Mkhadder ${ }^{c}$ Lucy Cooper, ${ }^{d}$ Martin Gorman, ${ }^{d}$ Intissar Bouzidi, ${ }^{c}$ Nathalie Guillou, ${ }^{d *}$ Guy De Weireld, ${ }^{a *}$ Thomas Devic ${ }^{\text {cd* }}$.

${ }^{a}$ Service de Thermodynamique et de Physique mathématique, Faculté Polytechnique, Université de Mons, 20, place du Parc, 7000 Mons, Belgium.

b MADIREL, UMR CNRS 7246, Université Aix-Marseille, Centre de St Jérôme, 13013 Marseille, France.

${ }^{\mathrm{c}}$ Institut des Matériaux Jean Rouxel (IMN), UMR 6502, CNRS Université de Nantes, 2 rue de la Houssinière, 44322 Nantes cedex 3, France.

d Institut Lavoisier, UMR CNRS 8180, Université de Versailles St-Quentin-en-Yvelines, Université Paris-Saclay, 45 Avenue des Etats-Unis, 78035 Versailles cedex, France.

\section{AUTHOR INFORMATION}

\section{Corresponding Author}

*nathalie.guillou@uvsq.fr, guy.deweireld@umons.ac.be, thomas.devic@cnrs-imn.fr. 
ABSTRACT The ability of two structurally related small pore Metal Organic Frameworks (MOFs) to capture $\mathrm{CO}_{2}$ was investigated by a combination of gas sorption measurements, $\mathrm{X}$-ray powder diffraction (XRPD) analysis, microcalorimetry experiments and Ideal Adsorbed Solution Theory (IAST) calculations. The title solids, formulated $\mathrm{Mg}\left(\mathrm{H}_{2}\right.$ gal $)$ and $\mathrm{Fe}(\mathrm{Hgal})\left(\mathrm{H}_{4} \mathrm{gal}=\right.$ gallic acid $)$ are made of a naturally occurring ligand, and were both prepared on the multigram scale under mild conditions. They both present very similar structures, with identical channels of ca $3.5 \AA$ diameter, but present different amounts of acidic protons on the surface of the pores. These compounds were found to be extremely hydrophilic, and exhibit a moderate stability towards water. Whilst their ability to adsorb $\mathrm{CH}_{4}$ and $\mathrm{N}_{2}$ is very limited, they both adsorb significant amounts of $\mathrm{CO}_{2}$ even at atmospheric pressure ( 3 and $5 \mathrm{mmol} \mathrm{g}^{-1}$ at $303 \mathrm{~K}$ for the $\mathrm{Fe}$ and $\mathrm{Mg}$ derivatives respectively). As a consequence, these compounds present high $\mathrm{CO}_{2} / \mathrm{N}_{2}$ and $\mathrm{CO}_{2} / \mathrm{CH}_{4}$ selectivities (380-910 and 190-460 respectively) together with good working capacities, making them of interest for the capture of $\mathrm{CO}_{2}$ from flue gas or for landfill gas upgrading in pressure swing adsorption or vacuum swing adsorption processes. Finally, the analysis of the Mg derivative by X-Ray Diffraction (XRD) and adsorption microcalorimetry revealed that its high affinity for $\mathrm{CO}_{2}$ relies on a strong and specific site of adsorption involving double hydrogen bonds between the $\mathrm{CO}_{2}$ molecules and the acidic protons of the framework. 


\section{Introduction}

After a long lasting quest for large pore Metal Organic Frameworks (MOFs) with very high sorption capacities suitable for gas storage or gas capture, nowadays small pore MOFs are considered with increasing interest. These solids appear particularly suitable for gas separation purposes, especially $\mathrm{CO}_{2}$ capture, ${ }^{1-5}$ as both enhanced guest-framework interactions through confinement and steric effects could give rise to very high selectivities, especially in the atmospheric pressure regime. ${ }^{6-11}$ Sustainable access to these materials is also a growing concern: the availability and toxicity of the reactants (organic and inorganic) and the solvent (not only for the synthesis but also the activation step) could play a major role if one truly envisions these MOFs for practical uses. ${ }^{12,13}$ Indeed, while water, and especially hydrothermal conditions, was commonly used from the beginning of the MOF era, the benefit of this solvent in terms of sustainability is nowadays stressed explicitly. ${ }^{14-18}$ Furthermore, preparation procedures involving solely this solvent, under mild conditions, using earth abundant cations (such as $\mathrm{Mg}, \mathrm{Al}, \mathrm{Ti}, \mathrm{Fe}$ ) and bio available ligands appear particularly appealing.

We have recently become interested in the use of phenolate ligands for the preparation of robust MOFs. ${ }^{19-21}$ Specifically, we reported the preparation of a 3-D solid made a naturally occurring phenolic derivative, namely gallic acid ( $\mathrm{H}_{4}$ gal $)$, and magnesium, on the $20 \mathrm{~g}(\sim 0.1 \mathrm{~mol})$ scale in water at atmospheric pressure. ${ }^{22}$ This compound, formulated $\mathrm{Mg}\left(\mathrm{H}_{2}\right.$ gal $) \cdot 2 \mathrm{H}_{2} \mathrm{O}$, is isostructural with the already reported $\mathrm{M}^{\mathrm{II}}=\mathrm{Ni}, \mathrm{Co}, \mathrm{Mn}$ solids, i.e. built up from chain of corner sharing $\mathrm{MO}_{6}$ octahedra connected through the ligands to afford interconnected triangular channels of ca. $3.5 \AA$ diameter (see Figure 1). ${ }^{23,24}$ The charge balance is ensured by the presence of two remaining 
protons on each ligand, located on the oxygen atom in meta position, as evidenced by neutron diffraction $(\mathrm{M}=\mathrm{Ni}, \mathrm{Co})^{23}$ and 2-D solid state NMR $(\mathrm{M}=\mathrm{Mg}) \cdot{ }^{22}$ One of the less common features of this structure type is that it also adapts to trivalent cations. The $\mathrm{Fe}^{\mathrm{III}}$ analogue was indeed reported in the early 90 's, ${ }^{25,26}$ and presents a similar structure except for the protonation state of the ligand, which is in this case $3 / 4$ deprotonated, giving rise to the formula $\mathrm{Fe}(\mathrm{Hgal}) \cdot 2 \mathrm{H}_{2} \mathrm{O}$. Whereas the structure and magnetic properties of these transition metal based solids were thoroughly studied, ${ }^{23,27}$ no information about their adsorptive properties was available. Nitrogen sorption experiments carried out at $77 \mathrm{~K}$ on the $\mathrm{Mg}$ derivative indicated that this solid is microporous, although the small size of the pores and their high polarity, associated with the presence of remaining acidic protons on the ligand, accounted for strong diffusion kinetics limitation at low temperature. ${ }^{22} \mathrm{We}$ therefore decided to investigate the sorptive properties of the $\mathrm{Mg}$ and Fe based solids around room temperature (298-303 K). By using a combination of X-ray powder diffraction (XRPD) analyses, single gases $\left(\mathrm{CO}_{2}, \mathrm{~N}_{2}, \mathrm{CH}_{4}\right)$ and water vapor sorption isotherm measurements as well as gas adsorption microcalorimetry, we were able to shed some light on the host-guest interactions of these solids, particularly on the role of acidic protons on their sorption ability. Eventually, calculations based on the Ideal Adsorbed Solution Theory (IAST) revealed that these compounds, which were very recently proposed for ethane-ethylene separation, ${ }^{28}$ could also be interesting for $\mathrm{CO}_{2} / \mathrm{N}_{2}$ separation in conditions relevant to $\mathrm{CO}_{2}$ capture from flue gas or for the $\mathrm{CO}_{2} / \mathrm{CH}_{4}$ separation in landfill gas upgrading. 

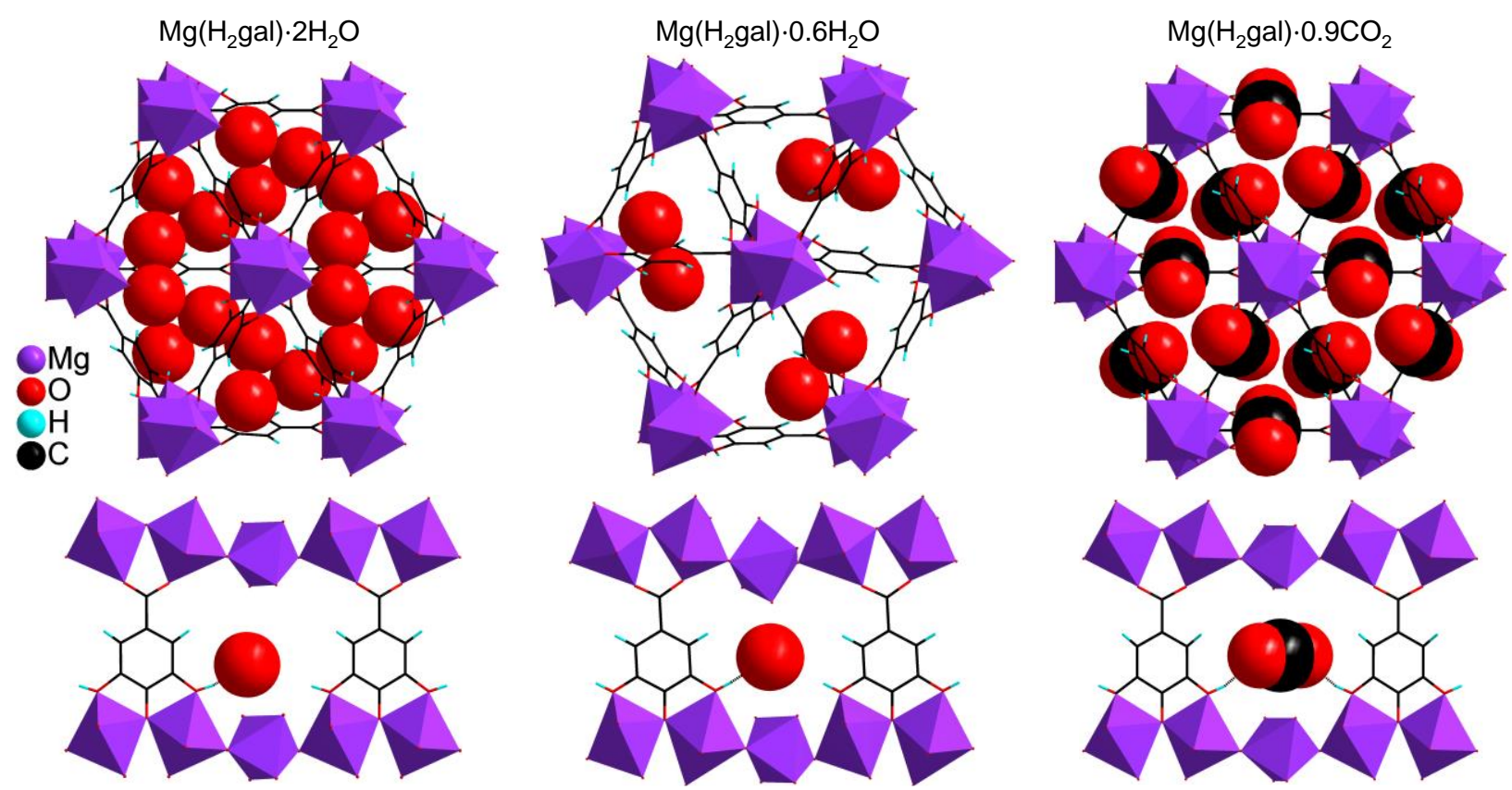

Figure 1. Crystal structures of $\mathrm{Mg}\left(\mathrm{H}_{2}\right.$ gal $) \cdot 2 \mathrm{H}_{2} \mathrm{O}, \mathrm{Mg}\left(\mathrm{H}_{2}\right.$ gal $) \bullet 0.6 \mathrm{H}_{2} \mathrm{O}$ and $\mathrm{Mg}\left(\mathrm{H}_{2}\right.$ gal $) \bullet 0.9 \mathrm{CO}_{2}$.

Top: view along the channel axis; bottom: highlight on the guest - framework $\mathrm{C}-\mathrm{O}-\mathrm{H} \cdot \bullet \cdot \mathrm{O}$

hydrogen bonds.

\section{Results and discussion}

$\mathrm{Mg}\left(\mathrm{H}_{2} \mathrm{gal}\right) \cdot 2 \mathrm{H}_{2} \mathrm{O}$ was prepared as previously reported. ${ }^{22}$ Several procedures were proposed to synthesize $\mathrm{Fe}(\mathrm{Hgal}) \cdot 2 \mathrm{H}_{2} \mathrm{O}$, including room temperature solution routes ${ }^{27}$ or diffusion within a gel, ${ }^{25}$ as well as conventional ${ }^{24,29}$ or microwave ${ }^{23}$ hydrothermal reactions, all starting from $\mathrm{Fe}^{\mathrm{II}}$ salts and $\mathrm{H}_{4}$ gal in water. We found that under mild conditions $(\mathrm{T}=353 \mathrm{~K}$ under stirring), it is possible to produce the title solid as a polycrystalline powder from iron(II) chloride and gallic acid on the multigram scale with a yield of $c a .65 \%$ (see supporting information for details). XRPD analysis confirmed that both solids belong to the expected structure type (Figure S1) and thermogravimetric (TG) analyses showed that the water content is $c a .2 \mathrm{H}_{2} \mathrm{O}$ per formula unit 
(Figure S4). A closer look at the TG data, as well as the corresponding Differential Scanning Calorimetry (DSC) signal, indicates that the water departure (endothermic) is almost concomitant with the beginning of the degradation of the network (exothermic), especially in the case of iron. The difference between $\mathrm{Fe}^{\mathrm{III}}$ and $\mathrm{Mg}^{\mathrm{II}}$ based solids could be explained both by the stronger waterphenol hydrogen bonds in the framework made of $\mathrm{Fe}^{\mathrm{III}}$ than of $\mathrm{Mg}^{\mathrm{II}}$, as already observed with other $\mathrm{M}^{\mathrm{II}}$ cations $(\mathrm{Ni}, \mathrm{Co}),{ }^{23}$ which render the departure of water more difficult, as well as by the lower thermal stability of the transition metal based solid (see Figure S4). Such a lower stability might be intrinsic property of the material, or be related to a different amount of defects, which are known to affect the stability of MOFs.

The high crystallinity of the Mg framework allowed us to study its dehydration by high resolution XRPD. While under air, only a contraction of the unit cell up to the degradation of the framework was observed, ${ }^{22}$ it was possible to isolate an intermediate form at $388 \mathrm{~K}$ under vacuum. Specifically, a few additional weak diffraction peaks were clearly discernible on the XRPD pattern, indicative of a superstructure. The diagram could indeed be indexed with a triple unit-cell (see Table 1), and the structure was ultimately refined satisfactorily through to the Rietveld method (see Figures 2 and S2 for the final refinement plot). Note here that single crystal analysis has revealed a similar feature upon dehydration of $\mathrm{Fe}(\mathrm{Hgal}) \cdot 2 \mathrm{H}_{2} \mathrm{O} .{ }^{30}$ In this form, the structure contains 3 independent cations and ligands (vs. one on twofold axes in the hydrated form), but no change in the topology of the network occurred (see Figure 1). The structural changes mostly relate to the strong distortion of two thirds of the $\mathrm{MgO}_{6}$ octahedra, associated with a dissymmetrisation of the phenol-Mg bonds (half of the $\mathrm{O}(\mathrm{H})-\mathrm{Mg}$ bonds are shortened, half are elongated, see Table 2). The coordination number of these $\mathrm{Mg}$ ions thus evolves from 6 to $5+1$, this modification being associated with a change in the $\mathrm{Mg}-\mathrm{O}-\mathrm{Mg}$ angles (from $130.0(1)^{\circ}$ in the hydrated solid to $122.3(1)$, 
123.7(1) and $130.8(1)^{\circ}$ in the present form). Regarding the gallate ligand, this distortion is associated with a slight rotation around the phenyl-carboxylate bond (the corresponding dihedral angles evolve from $34.9^{\circ}$ in the hydrated form to $24.1,31.3$ and $32.1^{\circ}$ in the present form). Regarding the pore content, the majority (ca. 70\%) of the water molecules were discarded, but the position of the remaining molecules is very similar to the one found in the fully hydrated form ${ }^{22}$ (see Figure 1).

Table 1. Refinement parameters for $\mathrm{Mg}\left(\mathrm{H}_{2} \mathrm{gal}\right) \bullet \mathrm{n}$ (guest).

\begin{tabular}{llll}
\hline Solid & $\mathrm{Mg}\left(\mathrm{H}_{2}\right.$ gal $) \cdot 2 \mathrm{H}_{2} \mathrm{O}$ & $\mathrm{Mg}\left(\mathrm{H}_{2}\right.$ gal $) \cdot 0.6 \mathrm{H}_{2} \mathrm{O}$ & $\mathrm{Mg}\left(\mathrm{H}_{2}\right.$ gal $) \bullet 0.9 \mathrm{CO}_{2}$ \\
\hline Formula & $\mathrm{MgO}_{7} \mathrm{C}_{7} \mathrm{H}_{8}$ & $\mathrm{MgO}_{5.64} \mathrm{C}_{7} \mathrm{H}_{5.28}$ & $\mathrm{MgO}_{6.84} \mathrm{C}_{7.92} \mathrm{H}_{4}$ \\
$M_{\mathrm{r}}$ & 228.44 & 203.96 & 232.97 \\
Crystal syst. & & \multicolumn{2}{c}{ Trigonal } \\
Space group & $P 3{ }_{1} 21$ & $P 3_{1}$ & $P 3{ }_{1} 21$ \\
$a(\AA)$ & $8.86705(6)$ & $15.12920(9)$ & $8.86013(5)$ \\
$c(\AA)$ & $10.77195(9)$ & $10.27856(9)$ & $10.8742(1)$ \\
$V\left(\AA^{3}\right)$ & $733.47(2)$ & $2037.49(3)$ & $739.28(2)$ \\
$Z$ & 3 & 9 & 3 \\
$\lambda(\AA)$ & & & 1.5405981 \\
Struc.param. & 22 & 57 & 24 \\
Nb. refl. & 196 & 1111 & 257 \\
$R_{\mathrm{p}}, R_{\text {wp }}$ & $0.031,0.044$ & $0.027,0.039$ & $0.022,0.032$ \\
$R_{\text {Bragg, }}$ GoF & $0.016,2.24$ & $0.019,3.00$ & $0.017,3.76$ \\
\hline
\end{tabular}



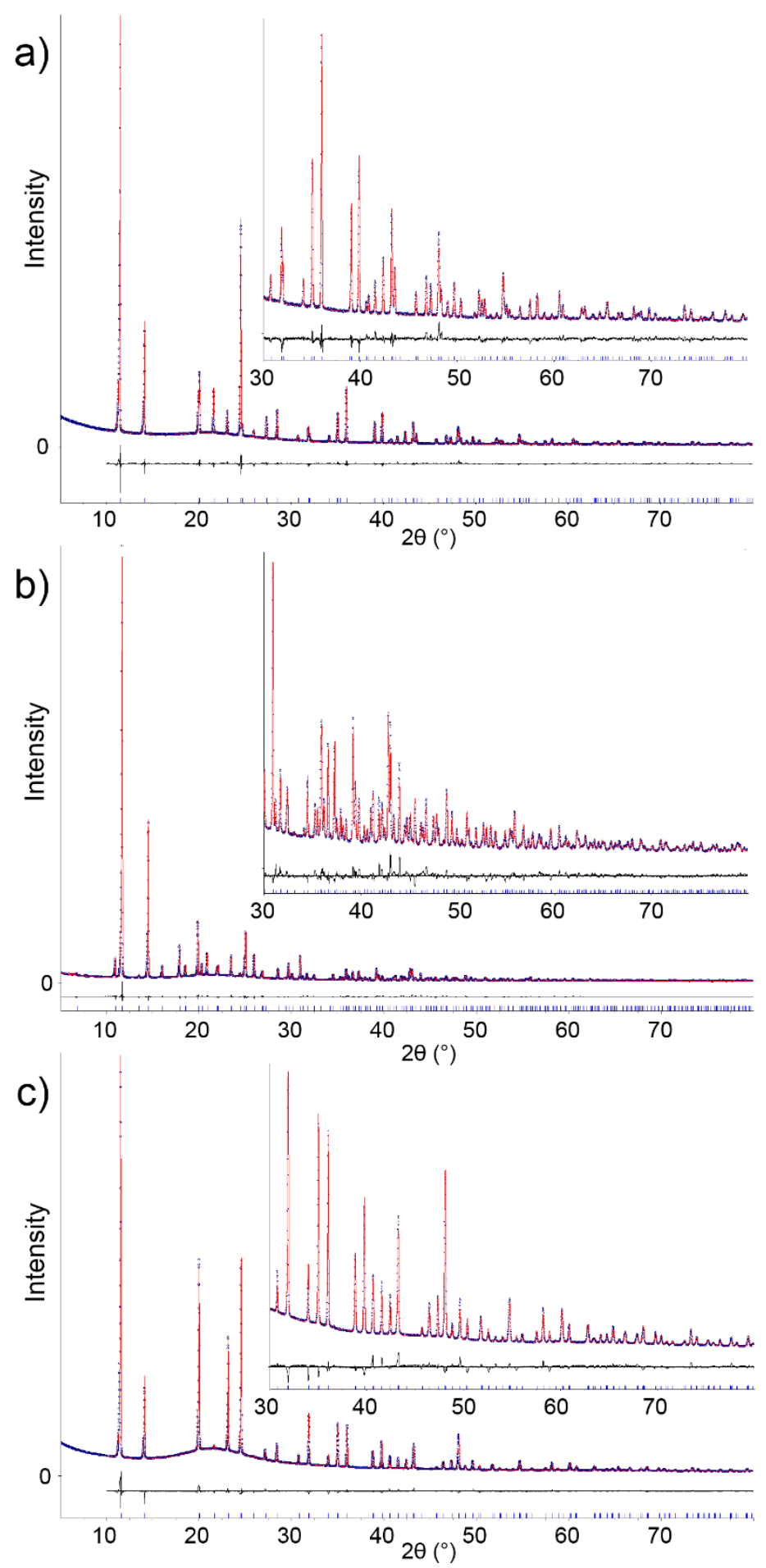

Figure 2. Final Rietveld plots in the $2 \theta$-range $5-80^{\circ}$ (see Figure $\mathrm{S} 2$ for the full range) for $\mathrm{Mg}\left(\mathrm{H}_{2}\right.$ gal) $\bullet 2 \mathrm{H}_{2} \mathrm{O}$ (top), $\mathrm{Mg}\left(\mathrm{H}_{2}\right.$ gal) $\bullet 0.6 \mathrm{H}_{2} \mathrm{O}$ (middle) and $\mathrm{Mg}\left(\mathrm{H}_{2}\right.$ gal) $\bullet 0.9 \mathrm{CO}_{2}$ (bottom). Inset: zoom on the $30-80^{\circ} 2 \theta$ range. 
Table 2. $\mathrm{Mg}-\mathrm{O}$ bond distances and bond valences (BV) in $\mathrm{Mg}\left(\mathrm{H}_{2}\right.$ gal $) \bullet n$ (guest).

\begin{tabular}{|c|c|c|c|}
\hline Oxygen & Mg-O distance $(\AA)$ & BV & Mg BV sum \\
\hline \multicolumn{4}{|c|}{$\mathrm{Mg}\left(\mathrm{H}_{2} \mathrm{gal}\right) \cdot 2 \mathrm{H}_{2} \mathrm{O}$} \\
\hline carboxylate & $2.047(3)(x 2)$ & 0.38 & \multirow[t]{3}{*}{2.18} \\
\hline$m$-phenol & $2.183(3)(\mathrm{x} 2)$ & 0.27 & \\
\hline$p$-phenolate & $1.998(1)(\mathrm{x} 2)$ & 0.44 & \\
\hline \multicolumn{4}{|c|}{$\mathrm{Mg}\left(\mathrm{H}_{2}\right.$ gal $) \bullet 0.6 \mathrm{H}_{2} \mathrm{O}$} \\
\hline \multirow[t]{2}{*}{ carboxylate } & $1.962(7)$ & 0.48 & \multirow[t]{6}{*}{2.21} \\
\hline & $2.21(1)$ & 0.25 & \\
\hline \multirow[t]{2}{*}{$m$-phenol } & $2.08(1)$ & 0.35 & \\
\hline & $2.36(1)$ & 0.17 & \\
\hline \multirow[t]{2}{*}{$p$-phenolate } & $1.950(7)$ & 0.50 & \\
\hline & $1.984(7)$ & 0.46 & \\
\hline \multirow[t]{2}{*}{ carboxylate } & $1.942(8)$ & 0.51 & \multirow[t]{6}{*}{2.34} \\
\hline & $2.10(1)$ & 0.33 & \\
\hline \multirow[t]{2}{*}{$m$-phenol } & $2.21(1)$ & 0.25 & \\
\hline & $2.26(1)$ & 0.22 & \\
\hline \multirow[t]{2}{*}{$p$-phenolate } & $1.922(7)$ & 0.54 & \\
\hline & $1.942(8)$ & 0.51 & \\
\hline \multirow[t]{2}{*}{ carboxylate } & $2.034(9)$ & 0.40 & \multirow[t]{6}{*}{2.12} \\
\hline & $2.126(5)$ & 0.31 & \\
\hline \multirow[t]{2}{*}{$m$-phenol } & $2.13(1)$ & 0.31 & \\
\hline & $2.36(1)$ & 0.16 & \\
\hline \multirow[t]{2}{*}{$p$-phenolate } & $1.96(1)$ & 0.49 & \\
\hline & $1.987(9)$ & 0.45 & \\
\hline \multicolumn{4}{|c|}{$\mathrm{Mg}\left(\mathrm{H}_{2} \mathrm{gal}\right) \bullet 0.9 \mathrm{CO}_{2}$} \\
\hline
\end{tabular}




\begin{tabular}{llll}
\hline carboxylate & $2.026(3)(\mathrm{x} 2)$ & 0.41 & 2.19 \\
$m$-phenol & $2.233(3)(\mathrm{x} 2)$ & 0.23 & \\
$p$-phenolate & $1.985(1)(\mathrm{x} 2)$ & 0.45 & \\
\hline $\mathrm{BV}=$ bond valence. & &
\end{tabular}

Such hemi-hydrated form presents a highly hydrophilic character: when stored within a dry glove box ( $<0.1 \mathrm{ppm}$ of water), the XRPD pattern of the hydrated form was recovered within few days. This was confirmed by the measurement of the vapor water sorption isotherm at $298 \mathrm{~K}$. After activation at $388 \mathrm{~K}$, as shown Figure 3, a type I isotherm is obtained, with a very steep adsorption at low pressure, and $\sim 80 \%$ of the maximal capacity $\left(\sim 10 \mathrm{mmol}\right.$ corresponding to $1.6 \mathrm{H}_{2} \mathrm{O}$ par formula unit, in line with the XRD analysis) reached even at $\mathrm{p} / \mathrm{p}^{\circ}=0.01$. The desorption branch overlaps with the adsorption one, suggesting a hydrolytic stability in these experimental conditions.

The stability of both the $\mathrm{Mg}$ and Fe solids towards water was further evaluated in suspension at room temperature (concentration $\left.1 \mathrm{mg} \cdot \mathrm{mL}^{-1}\right) \cdot \mathrm{Mg}\left(\mathrm{H}_{2} \mathrm{gal}\right) \cdot 2 \mathrm{H}_{2} \mathrm{O}$ completely lost its crystallinity within few hours, while $\mathrm{Fe}(\mathrm{Hgal}) \cdot 2 \mathrm{H}_{2} \mathrm{O}$ was found to degrade on the whole more slowly (main diffraction peak still discernible after $24 \mathrm{~h}$, see Figure S5). These results are in line with our previous findings, which evidenced the release of free gallic acid from $\mathrm{Mg}\left(\mathrm{H}_{2}\right.$ gal $) \cdot 2 \mathrm{H}_{2} \mathrm{O}$ under these experimental conditions, ${ }^{22}$ and suggest that $\mathrm{M}(\mathrm{II}, \mathrm{III})$ gallates present a limited hydrolytic stability, being able to stand in ambient air but degrading in the presence of a large amount of water (liquid phase). This agrees with the report from Ponce et al., who evidenced the instability of $\mathrm{Fe}(\mathrm{Hgal}) \cdot 2 \mathrm{H}_{2} \mathrm{O}$ under humid atmosphere at $373 \mathrm{~K},{ }^{29}$ but differs from the recent study of Bao et al., who claimed a high hydrolytic stability for $\mathrm{Mg}\left(\mathrm{H}_{2} \mathrm{gal}\right) \cdot 2 \mathrm{H}_{2} \mathrm{O}$, not only in air, but also in 
liquid water. ${ }^{28}$ In the latter case, the exact experimental conditions were not given, we postulate that a more concentrated suspension was used, hence preventing the complete dissolution of the title solid. Although unlikely because the synthetic conditions are very similar, the presence of a different amount of defects in both studies, which would also affect the stability of $\mathrm{Mg}\left(\mathrm{H}_{2} \mathrm{gal}\right) \cdot 2 \mathrm{H}_{2} \mathrm{O}$, cannot be ruled out.

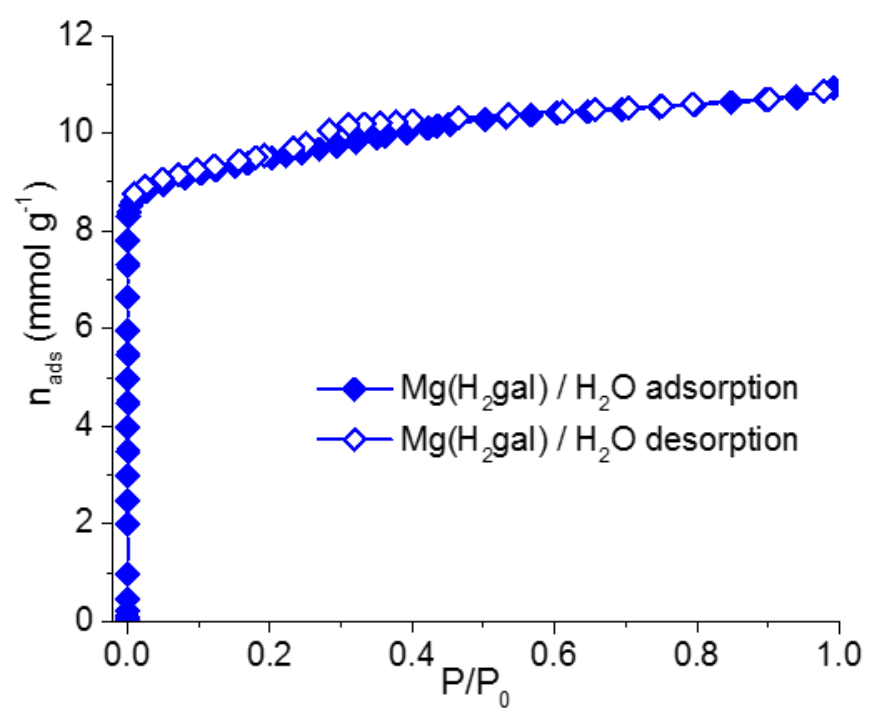

Figure 3. Sorption isotherms of $\mathrm{H}_{2} \mathrm{O}$ on $\mathrm{Mg}\left(\mathrm{H}_{2}\right.$ gal $)$ at $298 \mathrm{~K}$. The adsorption and desorption branches are shown in plain and empty symbols respectively.

Gas sorption properties of both solids were investigated, with the aim of evaluating their interest in $\mathrm{CO}_{2}$ capture processes $\left(\mathrm{CO}_{2} / \mathrm{N}_{2}\right.$ and $\left.\mathrm{CO}_{2} / \mathrm{CH}_{4}\right)$. Considering the moderate thermal stability of the title solids (see above), a first set of $\mathrm{CO}_{2}$ adsorption experiments was carried out to optimize the temperature of activation in the 353-393 K range. Maximal adsorption capacities were obtained after activation at $383(\mathrm{Fe})$ and $388 \mathrm{~K}(\mathrm{Mg})$, and these temperatures were selected for further experiments. Single gas adsorption isotherms of $\mathrm{CO}_{2}, \mathrm{CH}_{4}$ and $\mathrm{N}_{2}$ were collected for both solids at $303 \mathrm{~K}$. As shown Figure 4, whatever the cation, only very limited amounts of $\mathrm{N}_{2}$ were adsorbed, 
both at atmospheric pressure $\left(\mathrm{n}_{\mathrm{ads}}<0.1\right.$ and $<0.2$ mmol. $\mathrm{g}^{-1}$ at 1 bar for the Mg and Fe solids respectively) and high pressure ( $\mathrm{n}_{\mathrm{ads}} \sim 1.1$ and 1.9 mmol. $\mathrm{g}^{-1}$ at 30 bar for the $\mathrm{Mg}$ and Fe solids respectively). A similar trend was observed for $\mathrm{CH}_{4}\left(\mathrm{n}_{\text {ads }} \sim 0.2\right.$ and $0.5 \mathrm{mmol}^{-1}$ at 1 bar for the $\mathrm{Mg}$ and Fe solids respectively, and $\sim 1.9$ and $2.1 \mathrm{mmol}^{-1} \mathrm{~g}^{-1}$ at 30 bars).
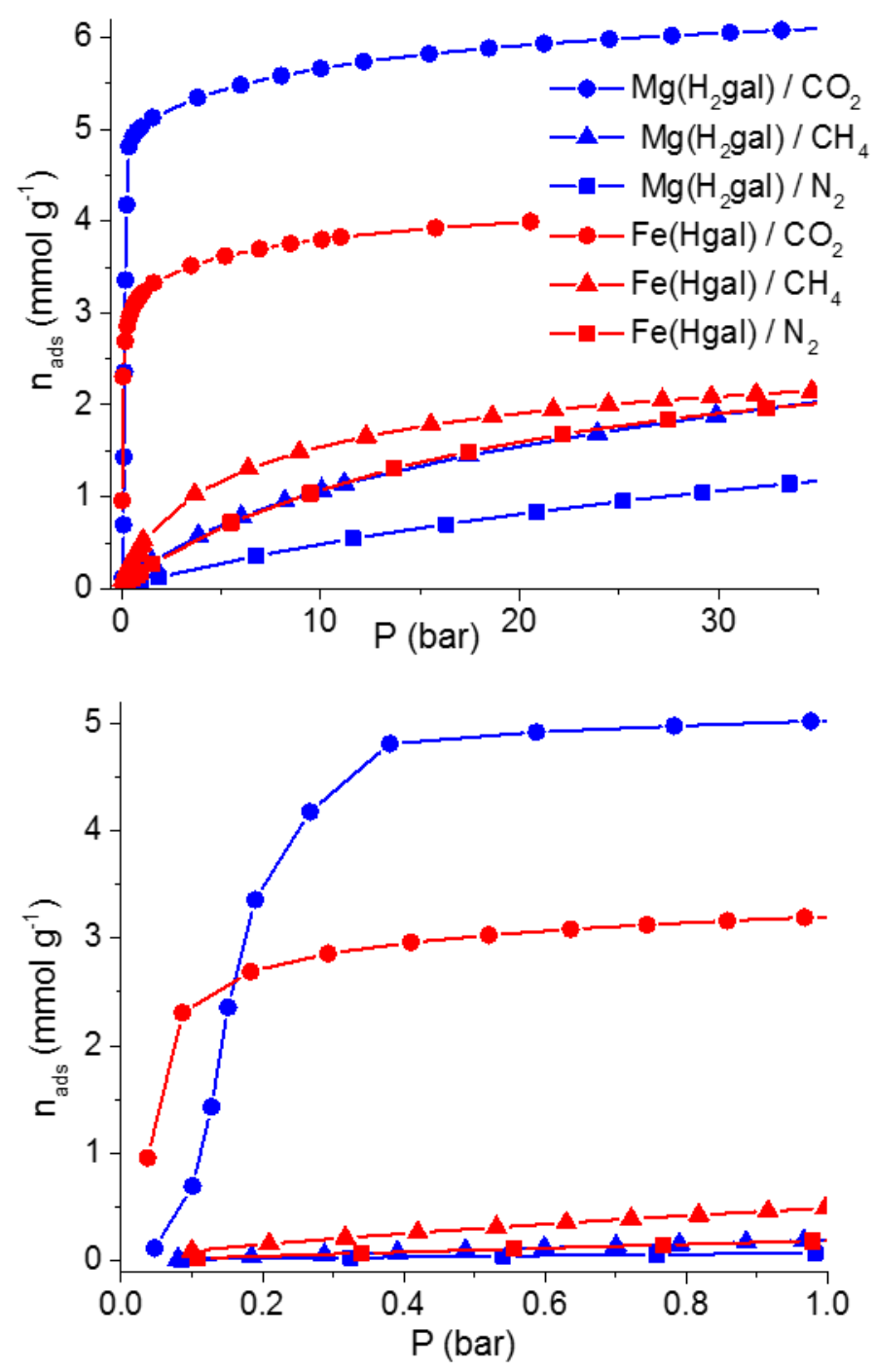

Figure 4. Adsorption isotherms of $\mathrm{CO}_{2}, \mathrm{~N}_{2}$ and $\mathrm{CH}_{4}$ on $\mathrm{Mg}\left(\mathrm{H}_{2}\right.$ gal) (blue) and $\mathrm{Fe}(\mathrm{Hgal})$ (red) at $303 \mathrm{~K}$. Both the 0-1 bar (bottom) and 0-35 bar (top) ranges are shown. 
This is in line with the low Henry constants extracted from the sorption isotherms for both $\mathrm{N}_{2}(0.18$ and $0.21 \mathrm{mmol} . \mathrm{g}^{-1} \cdot \mathrm{bar}^{-1}$ for the $\mathrm{Mg}$ and $\mathrm{Fe}$ solids respectively) and $\mathrm{CH}_{4}(0.2$ and 0.55 mmol.g${ }^{1}$. $\mathrm{bar}^{-1}$ for the $\mathrm{Mg}$ and $\mathrm{Fe}$ solids respectively). Such low capacities agree well with the small size of the pores ( $c a 3.5 \AA$ ). Conversely, very steep adsorption isotherms were observed for $\mathrm{CO}_{2}$ with both cations. At 0.15 bars, i.e. in conditions relevant for $\mathrm{CO}_{2}$ capture from flue gas (see below), both $\mathrm{Mg}$ and $\mathrm{Fe}$ based solids adsorb 2.4-2.5 mmol.g-1 ${ }^{-1}$, ranking them among the best behaving MOFs with no accessible metal sites..$^{9,11,31}$ Whereas the Fe derivative exhibits a standard type I isotherm, an inflexion point is reproducibly observed at ca. 0.1 bar for the $\mathrm{Mg}$ derivative, and is likely associated with a subtle structural transition (see above). At saturation, the $\mathrm{Mg}$ and $\mathrm{Fe}$ based solids adsorb about $6 \mathrm{mmol} . \mathrm{g}^{-1}$ and $4 \mathrm{mmol.g} \mathrm{g}^{-1}$ of $\mathrm{CO}_{2}$ respectively, which corresponds to $c a$. one molecule of $\mathrm{CO}_{2}$ per cation (1.15 and 0.9 mol.mol $^{-1}$ for the $\mathrm{Mg}$ and Fe based solids respectively).

Such results prompted us to evaluate the potentials of the title solid for $\mathrm{CO}_{2}$ separation and capture through co-adsorption prediction by Ideal Adsorbed Solution Theory (IAST). ${ }^{32}$ Two applications were considered, namely $\mathrm{CO}_{2}$ capture from (i) flue gas from power plants and (ii) landfill gas. For both, we determined selectivity and working capacity (see supporting information) which are two significant adsorbent selection criteria for pressure swing adsorption (PSA) and vacuum pressure swing adsorption (VSA) processes. ${ }^{1}$ For each process, the adsorption and desorption pressures has been selected according to usually used or recommended values from the literature. To be considered as interesting for such a process, an adsorbent must combine at least selectivity value higher than 30 and a working capacity higher than $1 \mathrm{mmol.g} \mathrm{g}^{-1}$ in operating conditions.

Regarding flue gas from power plant separation, we investigated $\mathrm{CO}_{2} / \mathrm{N}_{2}$ separation (10/90 and 15/85) using PSA (adsorption and desorption at 4 and 1 bar respectively ${ }^{33}$ ) and VSA processes (adsorption and desorption at 1 and 0.1 bar respectively ${ }^{1}$ ). Results are summarized in Table 3. 
Whatever the cation, high selectivity values were obtained in adsorption conditions. Moreover, the working capacities of $\mathrm{Mg}\left(\mathrm{H}_{2}\right.$ gal $)$ are very interesting for such a separation specially in PSA conditions. Compared to other MOFs which are classically only usable in VSA conditions due to very low working capacity in PSA conditions, $\mathrm{Mg}\left(\mathrm{H}_{2}\right.$ gal $)$ exhibits values higher than $2.4 \mathrm{mmol.g}{ }^{-}$ 1 that is very interesting for the adsorption process. Either in VSA or PSA conditions, the combination of high selectivity and high working capacity make this adsorbent promising for the considered separation (Table 4). ${ }^{1,34-37}$

Table 3. $\mathrm{CO}_{2} / \mathrm{N}_{2}$ selectivities and working capacities at $303 \mathrm{~K}$ obtained from IAST.

\begin{tabular}{llll}
\hline \multicolumn{3}{c}{$\mathrm{Mg}\left(\mathrm{H}_{2}\right.$ gal $)$} & \\
\hline $\mathrm{CO}_{2}: \mathrm{N}_{2}(\mathrm{at} \%)$ & $10: 90$ & $15: 85$ \\
\hline Selectivity & 1 bar & 377 & 477 \\
& 4 bar & 779 & 910 \\
\hline Working capacity $\left(\mathrm{mmol} \mathrm{g}^{-1}\right)$ & VSA & 1.7 & 2.5 \\
& PSA & 3.1 & 2.4 \\
\hline $\mathrm{CO}_{2}: \mathrm{N}_{2}($ at $\%)$ & $\mathrm{Fe}(\mathrm{Hgal})$ & & $15: 85$ \\
\hline Selectivity & & $10: 90$ & 625 \\
& 1 bar & 612 & 709 \\
\hline Working capacity $\left(\mathrm{mmol} \mathrm{g}^{-1}\right)$ & VSA & 680 & 1.6 \\
& PSA & 0.6 & 0.5 \\
\hline
\end{tabular}


Table 4. $\mathrm{CO}_{2} / \mathrm{N}_{2}$ selectivities and working capacities of benchmark materials.

\begin{tabular}{lllll}
\hline Adsorbent & Conditions & Selectivity & $\begin{array}{l}\text { Working capacity } \\
\left(\mathrm{mmol} \mathrm{g}^{-1}\right)\end{array}$ & Ref. \\
& & & 0.58 & 1 \\
\hline ZIF-78 & $10: 90 / 1-0.1 \mathrm{bar} / 298 \mathrm{~K}$ & 396 & 3.2 & 1 \\
CPO-27/MOF-74(Ni) & $10: 90 / 1-0.1 \mathrm{bar} / 298 \mathrm{~K}$ & 83.5 & 34 \\
CPO-27/MOF-74(Mg) & $15: 85 / 1-0.03 \mathrm{bar} / 298 \mathrm{~K}$ & 404 & 2.05 & 34 \\
zeolite 13X & $15: 85 / 1-0.03 \mathrm{bar} / 298 \mathrm{~K}$ & 981 & 1.03 & 35 \\
SIFSIX-3(Zn) & $15: 85 / 1-0.1 \mathrm{bar} / 298 \mathrm{~K}$ & 1700 & $1^{\mathrm{a}}$ & 36 \\
SIFSIX-3(Cu) & $15: 85 / 1-0.1 \mathrm{bar} / 298 \mathrm{~K}$ & 10500 & $0.45^{\mathrm{a}}$ & 37 \\
Zn(imPim) / MAF-stu-1 & $15: 85 / 1-0.1 \mathrm{bar} / 298 \mathrm{~K}$ & 106 & $2^{\mathrm{a}}$ & \\
\hline
\end{tabular}

${ }^{\mathrm{a}}$ Estimated from pure component isotherm graphics.

For Fe(Hgal), the working capacities in PSA process conditions are too low to consider this absorbent while the values in VSA conditions are high enough to reach the targets of such a process.

Regarding landfill gas separation, $\mathrm{CO}_{2} / \mathrm{CH}_{4}$ separation (50:50) using PSA (adsorption and desorption at 5 and 1 bar respectively ${ }^{1}$ ) and VSA processes (adsorption and desorption at 1 and 0.1 bar respectively $^{1}$ ) were considered. Selectivity and working capacity values are provided in Table 5. For both MOFs, very high values of selectivity were obtained for $\mathrm{CO}_{2} / \mathrm{CH}_{4}$ separation. However, working capacities in PSA conditions are too low to consider these adsorbents in such a process. On the other hand, in VSA conditions, the working capacities are more interesting. Notably, $\mathrm{Mg}\left(\mathrm{H}_{2}\right.$ gal $)$, with a working capacity of $4 \mathrm{mmol} \mathrm{g}^{-1}$, could be considered as a very promising candidate when compared to other MOFs (Table 6). ${ }^{1,38-40}$ 
Table 5. $\mathrm{CO}_{2} / \mathrm{CH}_{4}$ selectivities and working capacities at $303 \mathrm{~K}$ obtained from IAST.

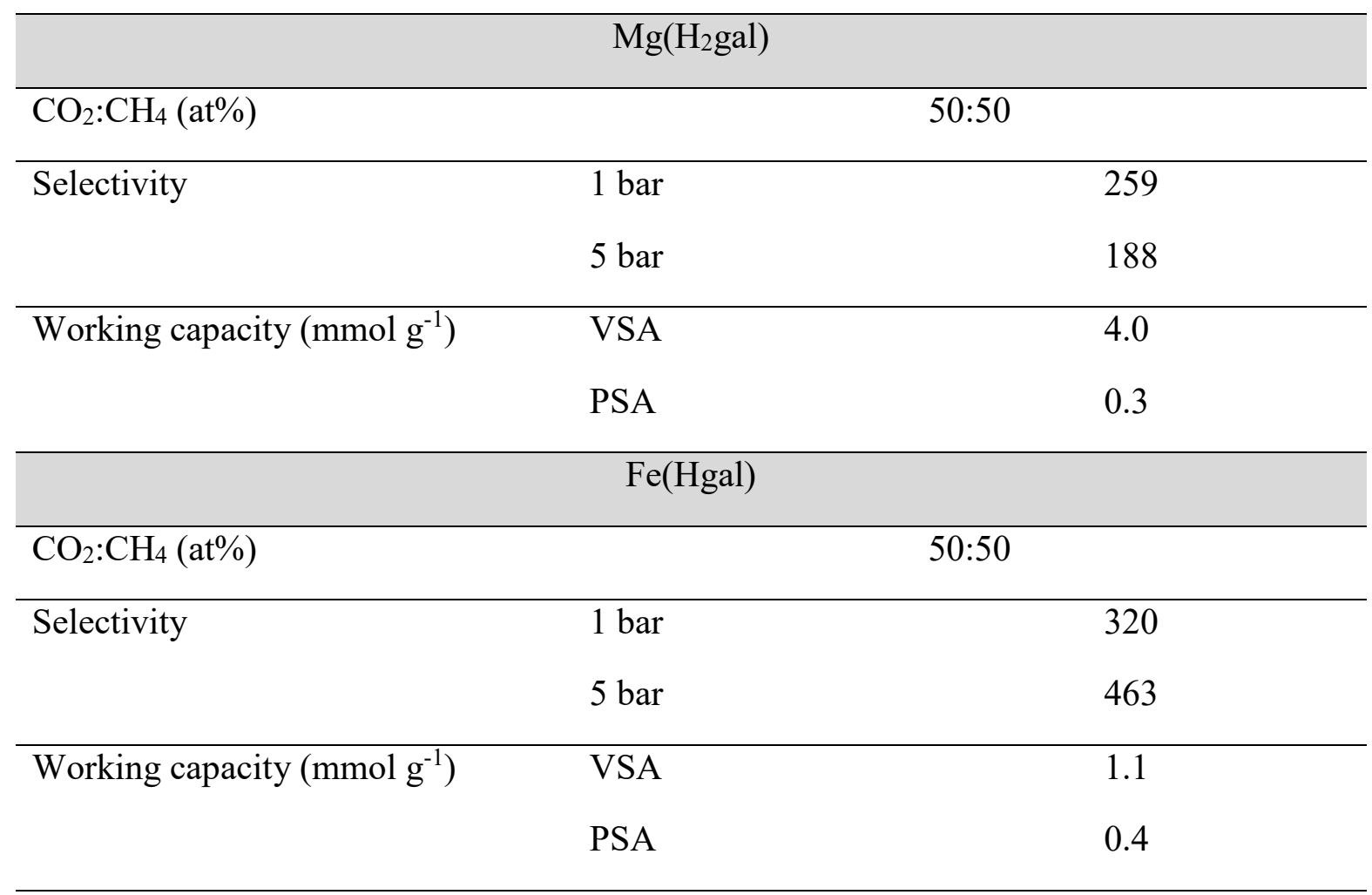

Table 6. $\mathrm{CO}_{2} / \mathrm{CH}_{4}$ selectivities and working capacities of benchmark materials.

\begin{tabular}{lllll}
\hline Adsorbent & Conditions & Selectivity & $\begin{array}{l}\text { Working capacity } \\
(\mathrm{mmol} / \mathrm{g})\end{array}$ & $\begin{array}{l}\text { Ref. } \\
\end{array}$ \\
& & & 2.33 & 1 \\
\hline CUK-1 & $50: 50 / 1-0.1 \mathrm{bar} / 298 \mathrm{~K}$ & 359 & 3.16 & 1 \\
CPO-27/MOF-74(Ni) & $50: 50 / 1-0.1 \mathrm{bar} / 298 \mathrm{~K}$ & 21 & 2.32 & 1 \\
CPO-27/MOF-74(Mg) & $50: 50 / 1-0.1 \mathrm{bar} / 298 \mathrm{~K}$ & 23.5 & 5.34 & 1 \\
HKUST-1 & $50: 50 / 5-1 \mathrm{bar} / 298 \mathrm{~K}$ & 21 & 1 \\
MOF-508b & $50: 50 / 5-1 \mathrm{bar} / 303 \mathrm{~K}$ & 10.9 & 2.58 & 38 \\
MIL-101(Cr) & $50: 50 / 5-1 \mathrm{bar} / 303 \mathrm{~K}$ & 9.5 & 3.2 & 39 \\
MIL-100(Cr) & $50: 50 / 5-1 \mathrm{bar} / 303 \mathrm{~K}$ & 6.5 & 2.5 & 40 \\
zeolite NaX & $50: 50 / 10-1 \mathrm{bar} / 300 \mathrm{~K}$ & 40 & 1.05 & \\
\hline
\end{tabular}


In order to get a deeper understanding of this high affinity for $\mathrm{CO}_{2}$ at the microscopic level, the structure of the $\mathrm{CO}_{2}$ loaded solid was investigated; the $\mathrm{Mg}$ derivative was chosen because of its higher crystallinity and better IAST performances. A capillary containing activated $\mathrm{Mg}\left(\mathrm{H}_{2}\right.$ gal $)$ together with 1 bar of $\mathrm{CO}_{2}\left(\mathrm{Mg}\left(\mathrm{H}_{2} \mathrm{gal}\right) \cdot 0.9 \mathrm{CO}_{2}\right)$ was subjected to XRPD at room temperature. The derived crystallographic parameters and the resulting Rietveld refinement are shown Table 1 and Figures 2 and $\mathrm{S} 2$ respectively. The unit-cell parameters are similar to the one of the hydrated solid, and $\mathrm{CO}_{2}$ molecules were found to be fully ordered. More precisely, as shown Figures 1 and $\mathrm{S} 3$, short intermolecular $\mathrm{O}($ phenol $) \cdots \cdots \mathrm{O}\left(\mathrm{CO}_{2}\right)$ contacts $(2.958(5) \AA)$ reveal that each $\mathrm{CO}_{2}$ molecule interacts with two phenolic groups through $\mathrm{C}-\mathrm{O}-\mathrm{H} \cdot \cdots \mathrm{OCO} \cdots \cdot \mathrm{H}-\mathrm{O}-\mathrm{C}$ hydrogen bonds $(\mathrm{H} \bullet \bullet \mathrm{O}$ and $\mathrm{O}-\mathrm{H} \bullet \bullet \mathrm{O}$ equal to $2.160(3) \AA$ and $161.1(2)^{\circ}$ respectively). Previous diffraction studies on $\mathrm{CO}_{2}$ loaded MOFs have shown that, apart from coordinatively unsaturated metal sites, ${ }^{41} \mathrm{CO}_{2}$ molecules generally interact with the framework either through donor-acceptor interactions (with $\mathrm{CO}_{2}$ acting either as the donor $(\mathrm{O})$ or the acceptor $(\mathrm{C}))^{42-45}$ or through single hydrogen bonds, ${ }^{46-48}$ and very rarely through double hydrogen bonds. ${ }^{46}$ The present adsorption site is rather unique, as it relies on both double hydrogen bonding with acidic protons and a good match of the metrics of the rigid framework and the $\mathrm{CO}_{2}$ molecule. Although acidic protons might also interact favorably with $\mathrm{N}_{2}$ and $\mathrm{CH}_{4}$, such a double interaction is unlikely because their size does not match with the phenolphenol distance. Moreover, considering the formula of the solid, we expect 1 mole of such a site per mole of material, i.e. a value very close the capacity at saturation. Hence, this analysis suggests that this solid exhibits a single, but strong and specific, site of adsorption for $\mathrm{CO}_{2}$.

Adsorption microcalorimetry measurements support these findings. Indeed, as shown Figure 5, the enthalpy associated with the adsorption of $\mathrm{CO}_{2}$ within $\mathrm{Mg}\left(\mathrm{H}_{2}\right.$ gal $)$ reached $-45 \mathrm{~kJ} \cdot \mathrm{mol}^{-1}$, a rather high value for a MOF without any accessible metal site, ${ }^{49}$ but is in line with the heat of adsorption 
of $\mathrm{CO}_{2}$ for other small pores MOFs. ${ }^{9,31}$ More importantly, this value remains constant up to $c a .4$ mmol. $\mathrm{g}^{-1}$, in agreement with the presence of homogenous sites of adsorption as described above.

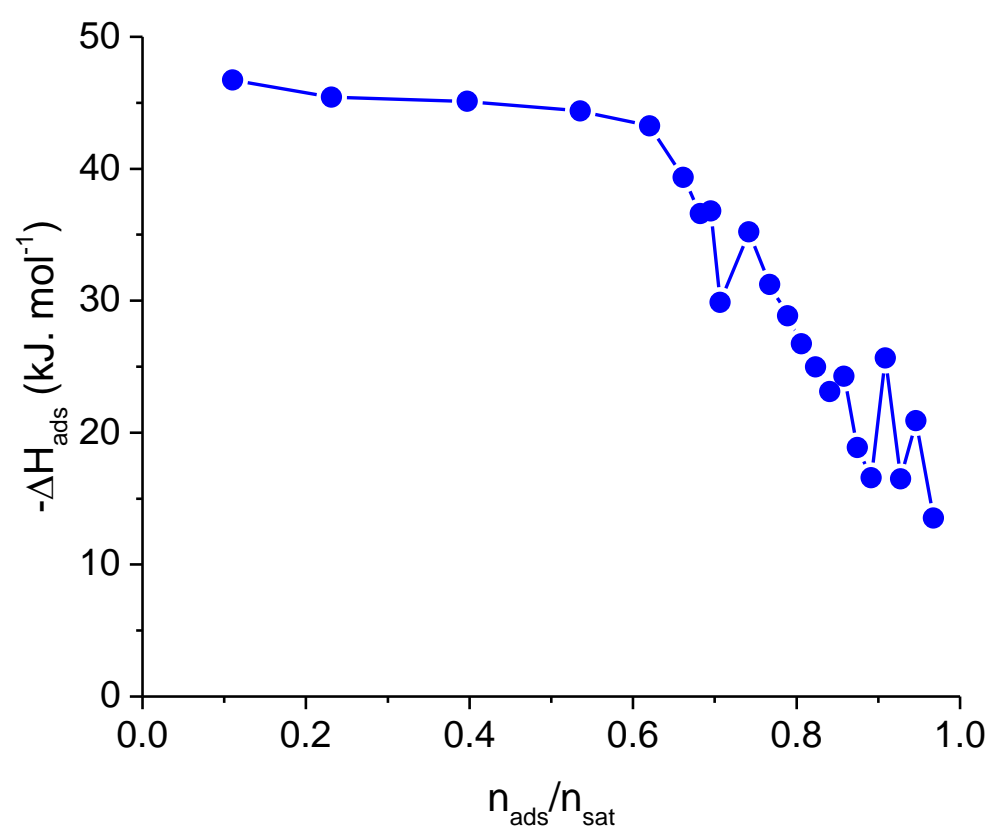

Figure 5. Differential enthalpies of adsorption of $\mathrm{CO}_{2}$ on $\mathrm{Mg}\left(\mathrm{H}_{2}\right.$ gal $)$ at $303 \mathrm{~K}$.

Finally, although the Langmuir fits used in the IAST calculations should always be considered with caution, they corroborate this result. As shown in table $\mathrm{S} 1$, the fit of the $\mathrm{CO}_{2}$ adsorption isotherm for $\mathrm{Mg}\left(\mathrm{H}_{2}\right.$ gal $)$ relies almost exclusively on one strong adsorption site, the second one being only active at high pressure (pore filling).

\section{Conclusion}

We have reported the adsorption properties of closely related small pores MOFs, presenting similar structures but different amount of acidic protons on their pore surface. The $\mathrm{Mg}$ and Fe solids were prepared equally easily on the multigram scale under mild and conditions from abundant and nontoxic precursors. ${ }^{22}$ Due to their limited pore size (ca. $3.5 \AA$ ), both solids adsorb minor amounts of 
$\mathrm{N}_{2}$ and $\mathrm{CH}_{4}$. However, $\mathrm{CO}_{2}$ is adsorbed in large amounts $\left(\sim 1 \mathrm{~mol}^{\mathrm{mol}}{ }^{-1}\right)$ even below atmospheric pressure. This behaviour is not only related to its smaller kinetic diameter, but also to strong and specific framework- $\mathrm{CO}_{2}$ hydrogen bonds, as indicated by XRPD analysis for the Mg based solid. Furthermore, IAST revealed that such solids present high $\mathrm{CO}_{2} / \mathrm{N}_{2}$ selectivities and good working capacity in VSA and/or PSA conditions They may, therefore, be of interest for $\mathrm{CO}_{2}$ capture from flue gases, but only under dry conditions, due to their hydrophilicity. ${ }^{50}$ For the purification of landfill gas, the Mg derivative might be interesting in VSA conditions, but again after the dehydration of raw gas.

\section{ASSOCIATED CONTENT}

Supporting Information. Synthesis, structure determination, thermal analyses, stability tests, adsorption measurement, IAST calculations. This material is available free of charge via the Internet at http://pubs.acs.org.

\section{AUTHOR INFORMATION}

\section{Notes}

The authors declare no competing financial interests.

\section{ACKNOWLEDGMENT}

The region Pays de la Loire is acknowledged for funding (project PSR 'MatHySE'), as well as the region Ile de France for the Ph.D fellowship of LC. S. Grolleau is thanked for the TG analyses. 


\section{REFERENCES}

(1) Bae, Y.-S.; Snurr, R. Q. Development and Evaluation of Porous Materials for Carbon Dioxide Separation and Capture. Angew. Chem. Int. Ed. 2011, 50, 11586-11596. https://doi.org/10.1002/anie.201101891.

(2) Kenarsari, S. D.; Yang, D.; Jiang, G.; Zhang, S.; Wang, J.; Russell, A. G.; Wei, Q.; Fan, M. Review of Recent Advances in Carbon Dioxide Separation and Capture. RSC Adv. 2013, 3, 22739-22773. https://doi.org/10.1039/C3RA43965H.

(3) Lee, S.-Y.; Park, S.-J. A Review on Solid Adsorbents for Carbon Dioxide Capture. J. Ind. Eng. Chem. 2015, 23, 1-11. https://doi.org/10.1016/j.jiec.2014.09.001.

(4) Sumida, K.; Rogow, D. L.; Mason, J. A.; McDonald, T. M.; Bloch, E. D.; Herm, Z. R.;

Bae, T.-H.; Long, J. R. Carbon Dioxide Capture in Metal-Organic Frameworks. Chem. Rev. 2012, 112, 724-781. https://doi.org/10.1021/cr2003272.

(5) Raza, A.; Gholami, R.; Rezaee, R.; Rasouli, V.; Rabiei, M. Significant Aspects of Carbon Capture and Storage - A Review. Petroleum 2019, 5, 335-340. https://doi.org/10.1016/j.petlm.2018.12.007.

(6) Shalini, S.; Nandi, S.; Justin, A.; Maity, R.; Vaidhyanathan, R. Potential of Ultramicroporous Metal-Organic Frameworks in $\mathrm{CO}_{2}$ Clean-Up. Chem. Commun. 2018, 54, 13472-13490. https://doi.org/10.1039/C8CC03233E.

(7) Zhang, Z.; Yao, Z.-Z.; Xiang, S.; Chen, B. Perspective of Microporous Metal-Organic Frameworks for $\mathrm{CO}_{2}$ Capture and Separation. Energy Environ. Sci. 2014, 7, 2868-2899. https://doi.org/10.1039/C4EE00143E. 
(8) Li, J.-R.; Sculley, J.; Zhou, H.-C. Metal-Organic Frameworks for Separations. Chem. Rev. 2012, 112, 869-932. https://doi.org/10.1021/cr200190s.

(9) Shekhah, O.; Belmabkhout, Y.; Chen, Z.; Guillerm, V.; Cairns, A.; Adil, K.; Eddaoudi, M. Made-to-Order Metal-Organic Frameworks for Trace Carbon Dioxide Removal and Air Capture. Nat. Commun. 2014, 5, 4228. https://doi.org/10.1038/ncomms5228.

(10) Liu, J.; Wei, Y.; Zhao, Y. Trace Carbon Dioxide Capture by Metal-Organic Frameworks. ACS Sustainable Chem. Eng. 2019, 7, 82-93. https://doi.org/10.1021/acssuschemeng.8b05590.

(11) Adil, K.; Belmabkhout, Y.; Pillai, R. S.; Cadiau, A.; Bhatt, P. M.; Assen, A. H.; Maurin, G.; Eddaoudi, M. Gas/Vapour Separation Using Ultra-Microporous Metal-Organic Frameworks: Insights into the Structure/Separation Relationship. Chem. Soc. Rev. 2017, 46, 3402-3430. https://doi.org/10.1039/C7CS00153C.

(12) Reinsch, H. “Green” Synthesis of Metal-Organic Frameworks. Eur. J. Inorg. Chem. 2016, 27, 4290-4299. https://doi.org/10.1002/ejic.201600286.

(13) Julien, P. A.; Mottillo, C.; Friščić, T. Metal-Organic Frameworks Meet Scalable and Sustainable Synthesis. Green Chem. 2017, 19, 2729-2747. https://doi.org/10.1039/C7GC01078H.

(14) Munn, A. S.; Dunne, P. W.; Tang, S. V. Y.; Lester, E. H. Large-Scale Continuous Hydrothermal Production and Activation of ZIF-8. Chem. Commun. 2015, 51, 12811-12814.

(15) Waitschat, S.; Reinsch, H.; Stock, N. Water-Based Synthesis and Characterisation of a New Zr-MOF with a Unique Inorganic Building Unit. Chem. Commun. 2016, 52, 12698-12701. https://doi.org/10.1039/C6CC06287C. 
(16) Garzon-Tovar, L.; Carne-Sanchez, A.; Carbonell, C.; Imaz, I.; Maspoch, D. Optimised Room Temperature, Water-Based Synthesis of CPO-27-M Metal-Organic Frameworks with High Space-Time Yields. J. Mater. Chem. A 2015, 3, 20819-20826.

(17) Huo, J.; Brightwell, M.; El Hankari, S.; Garai, A.; Bradshaw, D. A Versatile, Industrially Relevant, Aqueous Room Temperature Synthesis of HKUST-1 with High Space-Time Yield. $J$. Mater. Chem. A 2013, 1, 15220-15223.

(18) Cadot, S.; Veyre, L.; Luneau, D.; Farrusseng, D.; Alessandra Quadrelli, E. A Water-Based and High Space-Time Yield Synthetic Route to MOF $\mathrm{Ni}_{2}$ (DHTP) and Its Linker 2,5Dihydroxyterephthalic Acid. J. Mater. Chem. A 2014, 2, 17757-17763.

(19) Mouchaham, G.; Cooper, L.; Guillou, N.; Martineau, C.; Elkaïm, E.; Bourrelly, S.; Llewellyn, P. L.; Allain, C.; Clavier, G.; Serre, C.; et al. A Robust Infinite Zirconium Phenolate Building Unit to Enhance the Chemical Stability of Zr MOFs. Angew. Chem. Int. Ed. 2015, 54, 13297-13301. https://doi.org/10.1002/anie.201507058.

(20) Mouchaham, G.; Abeykoon, B.; Giménez-Marqués, M.; Navalon, S.; Santiago-Portillo, A.; Affram, M.; Guillou, N.; Martineau, C.; Garcia, H.; Fateeva, A.; et al. Adaptability of the Metal(III,IV) 1,2,3-Trioxobenzene Rod Secondary Building Unit for the Production of Chemically Stable and Catalytically Active MOFs. Chem. Commun. 2017, 53, 7661-7664. https://doi.org/10.1039/C7CC04215A.

(21) Cooper, L.; Guillou, N.; Martineau, C.; Elkaim, E.; Taulelle, F.; Serre, C.; Devic, T. Zr ${ }^{\mathrm{IV}}$ Coordination Polymers Based on a Naturally Occurring Phenolic Derivative. Eur. J. Inorg. Chem. 2014, 6281-6289. 
(22) Cooper, L.; Hidalgo, T.; Gorman, M.; Lozano-Fernandez, T.; Simon-Vazquez, R.; Olivier, C.; Guillou, N.; Serre, C.; Martineau, C.; Taulelle, F.; et al. A Biocompatible Porous Mg-Gallate Metal-Organic Framework as an Antioxidant Carrier. Chem. Commun. 2015, 51, 5848-5851.

(23) Saines, P. J.; Yeung, H. H. M.; Hester, J. R.; Lennie, A. R.; Cheetham, A. K. Detailed Investigations of Phase Transitions and Magnetic Structure in Fe(III), Mn(II), Co(II) and Ni(II) 3,4,5-Trihydroxybenzoate (Gallate) Dihydrates by Neutron and X-Ray Diffraction. Dalton Trans. 2011, 40, 6401-6410.

(24) Feller, R. K.; Cheetham, A. K. Fe(III), Mn(II), Co(II), and Ni(II) 3,4,5-Trihydroxybenzoate (Gallate) Dihydrates; a New Family of Hybrid Framework Materials. Solid State Sci. 2006, 8, $1121-1125$.

(25) Wunderlich, C.-H.; Weber, R.; Bergerhoff, G. Über Eisengallustinte. Z. Anorg. Allg. Chem. 1991, 598, 371-376. https://doi.org/10.1002/zaac.19915980134.

(26) Weber, R.; Bergerhoff, G. Crystal Structure of Iron(III) Oxonium 3,4,5Trihydroxybenzoate, $\left(\mathrm{C}_{7} \mathrm{H}_{2} \mathrm{O}_{5}\right) \mathrm{Fe}\left(\mathrm{H}_{3} \mathrm{O}\right)$. Z. Kristallo. 1991, 195, 87-88.

(27) Wagner, F. E.; Lerf, A. Mössbauer Spectroscopic Investigation of FeII and FeIII 3,4,5Trihydroxybenzoates (Gallates) - Proposed Model Compounds for Iron-Gall Inks. Z. Anorg. Allg. Chem. 2015, 641, 2384-2391. https://doi.org/10.1002/zaac.201500532.

(28) Bao, Z.; Wang, J.; Zhang, Z.; Xing, H.; Yang, Q.; Yang, Y.; Wu, H.; Krishna, R.; Zhou, W.; Chen, B.; et al. Molecular Sieving of Ethane from Ethylene through the Molecular CrossSection Size Differentiation in Gallate-Based Metal-Organic Frameworks. Angew. Chem. Int. Ed. 2018, 57, 16020-16025. https://doi.org/10.1002/anie.201808716. 
(29) Ponce, A.; Brostoff, L. B.; Gibbons, S. K.; Zavalij, P.; Viragh, C.; Hooper, J.; Alnemrat, S.; Gaskell, K. J.; Eichhorn, B. Elucidation of the Fe(III) Gallate Structure in Historical Iron Gall Ink. Anal. Chem. 2016, 88, 5152-5158. https://doi.org/10.1021/acs.analchem.6b00088.

(30) Zavalij, P. Y.; Stevens, L. M.; Eichhorn B. CCDC 1833913: Experimental Crystal Structure Determination, 2018, DOI: 10.5517/ccdc.csd.cc1zkbhc.

(31) Wen, H.-M.; Liao, C.; Li, L.; Alsalme, A.; Alothman, Z.; Krishna, R.; Wu, H.; Zhou, W.; Hu, J.; Chen, B. A Metal-Organic Framework with Suitable Pore Size and Dual Functionalities for Highly Efficient Post-Combustion $\mathrm{CO}_{2}$ Capture. J. Mater. Chem. A 2019, 7, 3128-3134. https://doi.org/10.1039/C8TA11596F.

(32) Myers, A. L.; Prausnitz, J. M. Thermodynamics of Mixed-Gas Adsorption. AIChE J. 1965, 11, 121-127. https://doi.org/10.1002/aic.690110125.

(33) Riboldi, L.; Bolland, O. Overview on Pressure Swing Adsorption (PSA) as $\mathrm{CO}_{2}$ Capture Technology: State-of-the-Art, Limits and Potentials. Energy Procedia 2017, 114, 2390-2400. https://doi.org/10.1016/j.egypro.2017.03.1385.

(34) Rajagopalan, A. K.; Avila, A. M.; Rajendran, A. Do Adsorbent Screening Metrics Predict Process Performance? A Process Optimisation Based Study for Post-Combustion Capture of $\mathrm{CO}_{2}$. Int. J. Greenhouse Gas Control 2016, 46, 76-85. https://doi.org/10.1016/j.ijggc.2015.12.033.

(35) Nugent, P.; Belmabkhout, Y.; Burd, S. D.; Cairns, A. J.; Luebke, R.; Forrest, K.; Pham, T.; Ma, S.; Space, B.; Wojtas, L.; et al. Porous Materials with Optimal Adsorption Thermodynamics and Kinetics for $\mathrm{CO}_{2}$ Separation. Nature 2013, 495, 80-84. https://doi.org/10.1038/nature11893. 
(36) Elsaidi, S. K.; Mohamed, M. H.; Schaef, H. T.; Kumar, A.; Lusi, M.; Pham, T.; Forrest, K. A.; Space, B.; Xu, W.; Halder, G. J.; et al. Hydrophobic Pillared Square Grids for Selective Removal of $\mathrm{CO}_{2}$ from Simulated Flue Gas. Chem. Commun. 2015, 51, 15530-15533. https://doi.org/10.1039/C5CC06577A.

(37) Wang, Z.-S.; Li, M.; Peng, Y.-L.; Zhang, Z.; Chen, W.; Huang, X.-C. An Ultrastable Metal Azolate Framework with Binding Pockets for Optimal Carbon Dioxide Capture. Angew. Chem. Int. Ed. 2019, 58, 16071-16076. https://doi.org/10.1002/anie.201909046.

(38) Llewellyn, P. L.; Bourrelly, S.; Serre, C.; Vimont, A.; Daturi, M.; Hamon, L.; De Weireld, G.; Chang, J.-S.; Hong, D.-Y.; Kyu Hwang, Y.; et al. High Uptakes of $\mathrm{CO}_{2}$ and $\mathrm{CH}_{4}$ in $\mathrm{Mesoporous}$ Metal Organic Frameworks MIL-100 and MIL-101. Langmuir 2008, 24, 7245-7250.

(39) Hamon, L.; Heymans, N.; Llewellyn, P. L.; Guillerm, V.; Ghoufi, A.; Vaesen, S.; Maurin, G.; Serre, C.; De Weireld, G.; Pirngruber, G. D. Separation of $\mathrm{CO}_{2}-\mathrm{CH}_{4}$ Mixtures in the Mesoporous MIL-100(Cr) MOF: Experimental and Modelling Approaches. Dalton Trans. 2012, $41,4052-4059$.

(40) Altintas, C.; Avci, G.; Daglar, H.; Nemati Vesali Azar, A.; Velioglu, S.; Erucar, I.; Keskin, S. Database for $\mathrm{CO}_{2}$ Separation Performances of MOFs Based on Computational Materials Screening. ACS Appl. Mater. Interfaces 2018, 10, 17257-17268. https://doi.org/10.1021/acsami.8b04600.

(41) Queen, W. L.; Brown, C. M.; Britt, D. K.; Zajdel, P.; Hudson, M. R.; Yaghi, O. M. SiteSpecific $\mathrm{CO}_{2}$ Adsorption and Zero Thermal Expansion in an Anisotropic Pore Network. J. Phys. Chem. C 2011, 115, 24915-24919. https://doi.org/10.1021/jp208529p. 
(42) C. Serre; S. Bourrelly; A. Vimont; N. A Ramsahye; G. Maurin; P. L Llewellyn; M. Daturi; Y. Filinchuk; O. Leynaud; P. Barnes; et al. An Explanation for the Very Large Breathing Effect of a Metal-Organic Framework during $\mathrm{CO}_{2}$ Adsorption. Adv. Mater. 2007, 19, 2246-2251.

(43) Vaidhyanathan, R.; Iremonger, S. S.; Shimizu, G. K. H.; Boyd, P. G.; Alavi, S.; Woo, T. K. Direct Observation and Quantification of $\mathrm{CO}_{2}$ Binding Within an Amine-Functionalized Nanoporous Solid. Science 2010, 330, 650-653. https://doi.org/10.1126/science.1194237.

(44) Mosca, N.; Vismara, R.; Fernandes, J. A.; Tuci, G.; Di Nicola, C.; Domasevitch, K. V.; Giacobbe, C.; Giambastiani, G.; Pettinari, C.; Aragones-Anglada, M.; et al. Nitro-Functionalized Bis(Pyrazolate) Metal-Organic Frameworks as Carbon Dioxide Capture Materials under Ambient Conditions. Chem. Eur. J. 2018, 24, 13170-13180. https://doi.org/10.1002/chem.201802240.

(45) Liang, W.; Bhatt, P. M.; Shkurenko, A.; Adil, K.; Mouchaham, G.; Aggarwal, H.; Mallick, A.; Jamal, A.; Belmabkhout, Y.; Eddaoudi, M. A Tailor-Made Interpenetrated MOF with Exceptional Carbon-Capture Performance from Flue Gas. Chem 2019, 5, 950-963. https://doi.org/10.1016/j.chempr.2019.02.007.

(46) Guillou, N.; Bourrelly, S.; Llewellyn, P. L.; Walton, R. I.; Millange, F. Location of $\mathrm{CO}_{2}$ during Its Uptake by the Flexible Porous Metal-Organic Framework MIL-53(Fe): A High Resolution Powder X-Ray Diffraction Study. CrystEngComm 2015, 17, 422-429. https://doi.org/10.1039/C4CE01393J.

(47) Yang, S.; Sun, J.; Ramirez-Cuesta, A. J.; Callear, S. K.; David, W. I. F.; Anderson, D. P.; Newby, R.; Blake, A. J.; Parker, J. E.; Tang, C. C.; et al. Selectivity and Direct Visualization of Carbon Dioxide and Sulfur Dioxide in a Decorated Porous Host. Nat. Chem. 2012, 4, 887-894. https://doi.org/10.1038/nchem.1457. 
(48) Lu, Z.; Godfrey, H. G. W.; da Silva, I.; Cheng, Y.; Savage, M.; Tuna, F.; McInnes, E. J. L.; Teat, S. J.; Gagnon, K. J.; Frogley, M. D.; et al. Modulating Supramolecular Binding of Carbon Dioxide in a Redox-Active Porous Metal-Organic Framework. Nat. Commun. 2017, 8, 14212. https://doi.org/10.1038/ncomms14212.

(49) Llewellyn, P. L.; Garcia-Rates, M.; GaberovÃ i, L.; Miller, S. R.; Devic, T.; Lavalley, J.C.; Bourrelly, S.; Bloch, E.; Filinchuk, Y.; Wright, P. A.; et al. Structural Origin of Unusual $\mathrm{CO}_{2}$ Adsorption Behavior of a Small-Pore Aluminum Bisphosphonate MOF. J. Phys. Chem. C 2015, $119,4208-4216$.

(50) Chanut, N.; Bourrelly, S.; Kuchta, B.; Serre, C.; Chang, J.-S.; Wright, P. A.; Llewellyn, P. L. Screening the Effect of Water Vapour on Gas Adsorption Performance: Application to $\mathrm{CO}_{2}$ Capture from Flue Gas in Metal-Organic Frameworks. ChemSusChem 2017, 10, 1543-1553. https://doi.org/10.1002/cssc.201601816. 


\section{TOC Graphic}

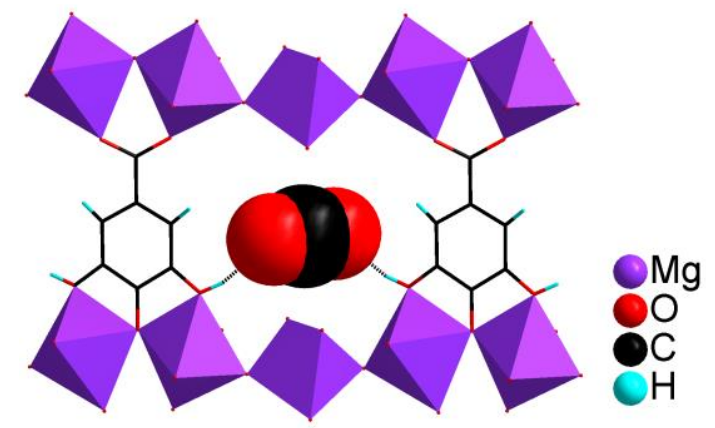

